\title{
Partial replacement and addition of fly ash in Portland cement: influences on carbonation and alkaline reserve
}

\author{
Marcelo Henrique Farias de Medeiros ${ }^{1} \cdot$ Janderson William Raisdorfer $^{1}$ • \\ Juarez Hoppe Filho $^{2} \cdot$ Ronaldo Alves Medeiros-Junior ${ }^{1,3}$
}

Received: 16 November 2016/Accepted: 7 March 2017/Published online: 14 March 2017

(C) Springer International Publishing Switzerland 2017

\begin{abstract}
This study aims to analyze the effect of using fly ash as a Portland cement additive or partial replacement in service conditions where carbonation acts as a degradation process. Fly ash was typified as anhydrous by XFR, XRD, modified Chapelle tests and laser granulometry. Five concretes were casted: one as reference (without additive), two with fly ash used as cement additive and two with fly ash used as a partial replacement of Portland cement. Replacement or additive levels were between 10 and $30 \%$ of cement mass. Those concretes were submitted to the compressive strength, accelerated carbonation and XRD tests using mortar extracted from the concrete in order to measure its alkaline supply. This researched allowed to conclude that alkaline reserve decreases and carbonation speed increases by adding or partially replacing the fly ash in the Portland cement. Besides, using fly ash reduces compressive strength at 28 days after wet cure. It is also important to highlight that there is an inverse correlation between alkaline reserve and carbonation speed in this case and, therefore, the remaining portlandite level is an important control factor in the carbonation process.
\end{abstract}

Keywords Carbonation $\cdot$ Degradation $\cdot$ Fly ash $\cdot$ Material properties

Ronaldo Alves Medeiros-Junior

ronaldodemedeirosjr@yahoo.com.br

1 Department of Civil Construction, Federal University of Parana-UFPR, Curitiba, Brazil

2 Department of Civil Engineering, Federal University of West of Bahia-UFOB, Barretos, Brazil

3 Centro Politecnico, Jardim das Americas-Curitiba, Parana, Brazil

\section{Introduction}

Mineral additives may be used for many different reasons, modifying several properties of the concrete. Examples of those effects have been studied and are cited in the following studies: (a) Wang and Baxter [1] showed that the replacement of $25 \%$ of cement by fly ash has a similar compressive strength when compared to pure cement concrete at 1 and 12 months. (b) Hoppe Filho et al. [2] showed that pozzolanic materials tend to reduce the expansion of the cementitious composites caused by sodium sulfate attack. (c) Choi et al. [3] replaced 20\% of Portland cement by fly ash (w/b ratios $=0.31,0.35$ and 0.50 ) showing that the use of fly ash has beneficial effects on the corrosion resistance of the steel in concrete due to the reduced permeability of chloride ions. (d) Chindaprasirt et al. [4] showed that pore size distribution and the average pore diameter of blended cement paste containing fly ash decreased when fly ash content and fineness increased. (e) Chindaprasirt et al. [5] showed that the blended cement paste containing fly ash generally had a smaller pore size than the paste of Portland cement type I. Moreover, the intensity of the XRD peak of $\mathrm{Ca}(\mathrm{OH})_{2}$ of a blended cement paste containing fly ash decreased when fly ash content and fineness increased. This study concluded that the hydration reaction, pozzolanic reaction, packing effect, and nucleation effect were enhanced by incorporating finer fly ashes. As a result, the paste with the finer fly ash has lower $\mathrm{Ca}(\mathrm{OH})_{2}$ and becomes denser than the paste with the coarser fly ash. (f) Shehata and Thomas [6] showed that fly ash is most effective in reducing the alkalinity of the pore solution and also better for controlling ASR expansion. Hoppe Filho [7] showed that fly ash tends to reduce the alkalinity of the concrete due to calcium hydroxide consumption, which is the main controlling factor of $\mathrm{pH}$ in 
cement pastes. (g) Hoppe Filho et al. [8] investigated the use of high contents of fly ash in the concrete mix proportion and also showed great decrease of the chloride diffusion coefficient in concretes with fly ash in their composition. (h) Heede and Belie [9] studied concretes with $15 \%$ of the Portland cement replaced by fly ash, using accelerated carbonation test and reinforcement depassivation time. In this study the estimated service life of concretes exposed to the carbonation process was over 100 years. However, it should be emphasized that Heede and Belie [9] had the same w/b ratio or lower than 0.45 in all of the evaluated mix proportions and, according to Possan [10] and Papadakis [11], for w/b ratios lower than 0.45 it is possible to consider that the carbonation rate is almost negligible. However, over this limit the increase of the w/b ratio and of the pozzolanic content might accelerate the carbonation process. Therefore, concretes produced with pozzolanic additions demand a careful mix proportioning.

In this context, the objective of this article is to study the relation between the alkaline reserve of the concrete and its carbonation, trying to explain the influence of fly ash in the durability of concretes exposed to carbon dioxide. The main contribution of this work was to try to relate the intensity of the portlandite peak and the portlandite amount by stoichiometry with the carbonation rate in order to understand if the alkaline reserve can be used to explain the carbonation speed of concretes with fly ash. The importance of this study is that the addition of fly ash in cement is being increasingly used and the change that this may cause regarding the durability of the concrete has to be more studied and understood.

Fly ash is used in Brazil in high amounts of replacement, such as between 15 and $50 \%$ in the production of CPIV [12] cement and between 6 and 14\% in the production of CPIIZ [13] cement.

The decrease of the portlandite of cement composite materials may facilitate the carbonation process, however, refinement of the pores due to the pozzolanic activity and an increase in particle packing tends to create a physical barrier hindering $\mathrm{CO}_{2}$ input, reducing carbonation effects. Therefore, carbonation is not exclusively related with the alkalinity of the concrete and this was investigated in this work.

\section{Experimental program}

In this study, the concrete mixes were designed using the following concepts: (1) fly ash as a partial replacement to Portland cement content; (2) fly ash as an addition to cement content. The reason of using those two methods of study is because there really are two possibilities of using mineral additions during the design of the concrete mix.

Another reason for using fly ash with those two ways of selecting the proportions of the concrete during the mix design is that they may have very distinct effects on the mechanical and durability properties of the produced concrete. The partial replacement of Portland cement alone may reduce the alkaline reserve due to the smaller formation of portlandite by volume $\left(\mathrm{m}^{3}\right)$ of concrete. Besides, fly ash has pozzolanic action and should consume part of the portlandite resulting from the Portland cement hydration. Thus, both methods of creating the mix design of the concrete will have different magnitudes of effects in the alkaline reserve of the produced concrete and this may influence both durability and mechanical resistance. This work is focused in the influence regarding the attack by carbon dioxide that produces the carbonation effect and corrosion in the steel of reinforced concrete structures.

The purest cement in the Brazilian market, CPV, was chosen, since this is a study regarding fly ash effects. This cement is equivalent to ASTM cement type III (Portland cement with high early strength). Fly ash was employed with replacement and addition levels of $10 \%$ (in order to simulate CPIIE specifications) and $30 \%$ (in order to simulate CPIV specifications) by mass of Portland cement (CPV). Those percentages were chosen in order to emulate cement with both high and low levels of fly ash.

Table 1 Concrete material proportions

\begin{tabular}{|c|c|c|c|c|c|c|}
\hline \multicolumn{7}{|c|}{ Theoretical unit mix proportion } \\
\hline \multicolumn{2}{|c|}{ Cement } & Sand & Gravel & $\mathrm{w} / \mathrm{b}$ & \multicolumn{2}{|c|}{ Cement content $\left(\mathrm{kg} / \mathrm{m}^{3}\right)$} \\
\hline 1 & & 2.25 & 3 & 0.5 & 353.08 & \\
\hline \multicolumn{7}{|c|}{ Mix proportion in mass (reference) } \\
\hline $\mathrm{w} / \mathrm{b}$ & $\begin{array}{l}\text { Vol } \\
\left(\mathrm{m}^{3}\right)\end{array}$ & $\begin{array}{l}\text { Cemen } \\
(\mathrm{Kg})\end{array}$ & & $\begin{array}{l}\text { Sand } \\
(\mathrm{kg})\end{array}$ & $\begin{array}{l}\text { Gravel } \\
(\mathrm{kg})\end{array}$ & $\begin{array}{l}\text { Water } \\
(\mathrm{kg})\end{array}$ \\
\hline 0.50 & 1.00 & 353.08 & & 794.43 & 1059.24 & 176.5 \\
\hline \multicolumn{7}{|c|}{$10 \%$ replacement (in cement mass) } \\
\hline & $\begin{array}{l}\text { Fly } \\
\text { ash }\end{array}$ & Cement & Sand & Gravel & Water & $\begin{array}{l}\text { Admixture } \\
(\%)\end{array}$ \\
\hline S10 & 35.31 & 317.77 & 794.43 & 1059.24 & 176.54 & 0.70 \\
\hline S30 & 105.92 & 247.16 & 794.43 & 1059.24 & 176.54 & 0.74 \\
\hline \multicolumn{7}{|c|}{$10 \%$ addition (in cement mass) } \\
\hline & $\begin{array}{l}\text { Fly } \\
\text { ash }\end{array}$ & Cement & Sand & Gravel & Water & $\begin{array}{l}\text { Admixture } \\
(\%)\end{array}$ \\
\hline A10 & 35.31 & 353.08 & 794.43 & 1059.24 & 194.19 & 1.00 \\
\hline $\mathrm{A} 30$ & 105.92 & 2353.08 & 794.43 & 1059.24 & 229.50 & 1.26 \\
\hline
\end{tabular}


Table 1 shows a summary of the concretes used. It is important to note that $\mathrm{w} / \mathrm{b}$ ratio was kept constant and the concrete had its fluidity set in order to have a slump of $10 \pm 2 \mathrm{~cm}$. A polycarboxylate ether based superplasticizer with density of $1.07 \mathrm{~g} / \mathrm{cm}^{3}$ and $\mathrm{pH}$ of $4.5 \pm 1.0$ was used for regulating fluidity. Compressive strength was a control criterion in this study and it was performed based on cylindrical test specimens of $\varnothing 10 \times 20 \mathrm{~cm}$. This test was executed with concrete with 28 days of submerse cure. A press with load speed in the range of $0.45 \pm 0.15 \mathrm{MPa} / \mathrm{s}$ was used. For each one of the test series, five repetitions were executed.

\subsection{Accelerated carbonation test}

The internal conditions of the carbonation chamber were controlled in order to have $5 \pm 1 \%$ of $\mathrm{CO}_{2}$ and $65 \pm 5 \%$ of relative humidity. Test samples used were $\varnothing 10 \times 20 \mathrm{~cm}$ cylinders and the readings were executed from the external face towards the center of the circumference, as shown in Fig. 1. For each fractured test specimen six readings were made, one at each $60^{\circ}$.

Carbonation depth readings by the phenolphthalein method were collected at $1,4,8$ and 12 months in order to obtain the carbonation coefficients $\left(K_{\mathrm{CO} 2}\right)$. These readings were adjusted based on Tuutti's [14] model shown in Eq. (1) where $e_{c}$ is the carbonated depth, $K_{\mathrm{CO}_{2}}$ is the carbonation coefficient to be calculated and $t$ is time in weeks.

$e_{c}=K_{\mathrm{CO}_{2}} \sqrt{t}$

As the result of carbonation reading behaves as an exponential equation, the time versus carbonation depth graph was linearized based on the squared root representation of time $t$ for determining $K_{\mathrm{CO} 2}$ value, as shown in Fig. 2. Thus, $K_{\mathrm{CO} 2}$ is the tangent of the slope angle $(\mathrm{mm} /$ week $^{0,5}$ ).

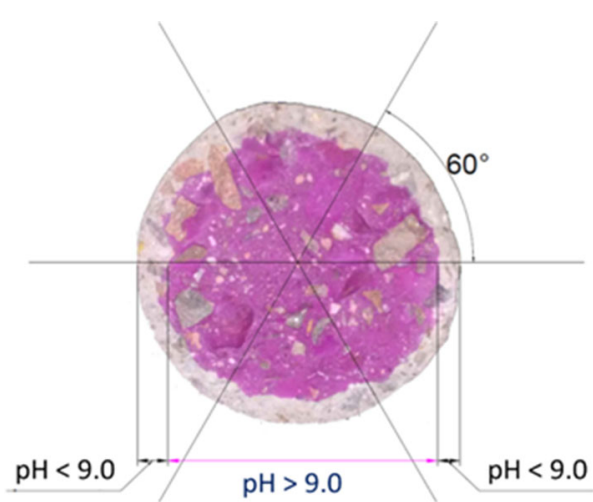

Fig. 1 Carbonation depth reading diagram

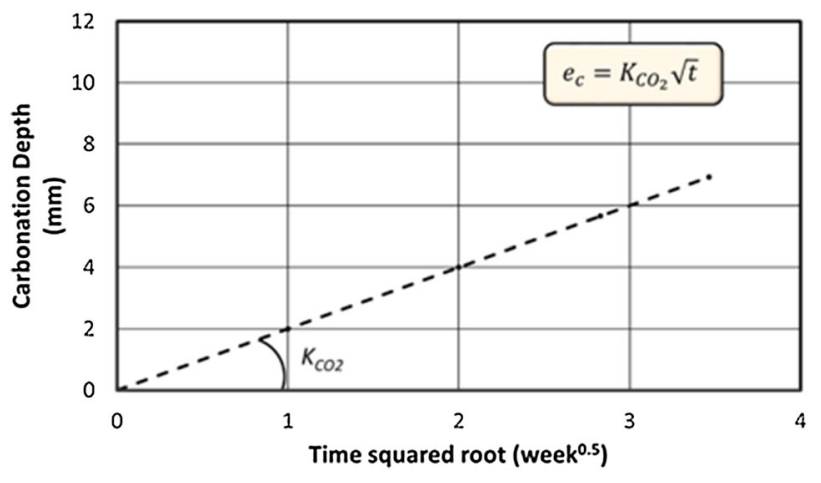

Fig. 2 Carbonation depth versus squared root of time

\subsection{X-rays diffractometer (XRD)}

This technique was used twice during this study: (1) for the pozzolanicity characterization of fly ash in anhydrous state; (2) for portlandite consumption caused by fly ash in mortar samples extracted from the five tested concretes.

Concrete mortar samples were collected by using a sledgehammer and a chisel, and then grinded with a mortar and a pestle, both ceramic ones, and dried in microwave during 9 min, according to Cabrera and Rojas [15]. After drying, samples were stored in $2 \mathrm{ml}$ Eppendorf and stocked in a polymeric container containing silica gel.

The samples of fly ash in anhydrous state and of the grinded mortar were prepared by manually pressing in the sample holder. The equipment used was the RIGAKU Ultimas IV X-ray diffractometer. Reading was made between $5^{\circ}$ and $75^{\circ} 2 \theta$, with a $0.02^{\circ} 2 \theta$ angular pitch and time per pitch of $1 \mathrm{~s}$. The analysis used a tube containing a copper anode, $40 \mathrm{~V} / 30 \mathrm{~mA}$ and a divergent slit of $1^{\circ}$.

\subsection{Modified Chapelle}

Modified Chapelle test is a method for the determination of pozzolanic activity by means of measuring the fixed level of calcium hydroxide. This is a method standardized in Brazil according to NBR 15895 [16] and its result is expressed by the amount consumed of calcium hydroxide per gram of pozzolanic material $\left(\mathrm{mg} \mathrm{Ca}(\mathrm{OH})_{2} / g\right.$ pozzolan).

The modified Chapelle test allows the determination of the mineral addition pozzolanicity, in its fineness for use, by means of the lime reaction rate after a standard time and with reaction being powered by heat. In other words, a particular amount of a supposed pozzolanic material $(1 \mathrm{~g})$ and of $\mathrm{CaO}(2 \mathrm{~g})$ are heated in water bath $\left(90 \pm 5^{\circ} \mathrm{C}\right)$ in order to chemically react. The mix is kept reacting during $16 \mathrm{~h}$. Consumed lime is calculated by the difference between the added and the residual lime after the test. The pozzolanicity of the materials is confirmed by calcium oxide over $330 \mathrm{mg} \mathrm{CaO} / \mathrm{g}$ of pozzolan. By stoichiometry, this value corresponds to $436 \mathrm{mg} \mathrm{Ca}(\mathrm{OH})_{2} / \mathrm{g}$ of pozzolan. 
Table 2 Physical and mechanical characteristics of the CPV Portland cement

\begin{tabular}{|c|c|c|c|c|c|c|c|c|c|c|}
\hline \multicolumn{7}{|c|}{ Physical analysis } & \multicolumn{4}{|c|}{ Mechanical analysis (compressive strength) } \\
\hline $\begin{array}{l}\text { expansion } \\
\text { hot }\end{array}$ & $\begin{array}{l}\text { Initial setting } \\
\text { time (h) }\end{array}$ & $\begin{array}{l}\text { Final setting } \\
\text { time }(\mathrm{h})\end{array}$ & $\begin{array}{l}\text { Normal } \\
\text { consistency }(\%)\end{array}$ & $\begin{array}{l}\text { Blaine } \\
\left(\mathrm{cm}^{2} / \mathrm{g}\right)\end{array}$ & $\begin{array}{l}\# 200 \\
(\%)\end{array}$ & $\begin{array}{l}\# 325 \\
(\%)\end{array}$ & $\begin{array}{l}1 \text { day } \\
\text { (MPa) }\end{array}$ & $\begin{array}{l}3 \text { days } \\
(\mathrm{MPa})\end{array}$ & $\begin{array}{l}7 \text { days } \\
\text { (MPa) }\end{array}$ & $\begin{array}{l}28 \text { days } \\
(\mathrm{MPa})\end{array}$ \\
\hline 0.50 & $02: 20$ & $3: 00$ & 28 & 4.130 & 0.40 & 3.60 & 22.5 & 34.8 & 42.00 & 48.8 \\
\hline
\end{tabular}

Table 3 X-Ray Fluorescence of CPV and fly ash

\begin{tabular}{llllllllllllllll}
\hline Samples & \multicolumn{10}{ll}{ Chemical composition (\%) } \\
\cline { 2 - 13 } & $\mathrm{SiO}_{2}$ & $\mathrm{~K}_{2} \mathrm{O}$ & $\mathrm{Fe}_{2} \mathrm{O}_{3}$ & $\mathrm{CaO}$ & $\mathrm{Al}_{2} \mathrm{O}_{3}$ & $\mathrm{P}_{2} \mathrm{O}_{5}$ & $\mathrm{TiO}_{2}$ & $\mathrm{SO}_{3}$ & $\mathrm{MgO}$ & $\mathrm{ZnO}$ & $\mathrm{MnO}$ & $\mathrm{CuO}$ & $\mathrm{Rb}_{2} \mathrm{O}$ & $\mathrm{Tm}_{2} \mathrm{O}_{3}$ & $\mathrm{SrO}$ \\
\hline $\mathrm{CPV}$ & 10.45 & 1.36 & 3.71 & 73.21 & 3.59 & - & 0.26 & 3.05 & 3.66 & 0.02 & 0.14 & - & - & 0.11 & 0.43 \\
Fly ash & 57.80 & 3.00 & 6.20 & 1.60 & 26.30 & 0.10 & 1.30 & 0.30 & 0.80 & 0.09 & 0.09 & - & 0.10 & - & 0.10 \\
\hline
\end{tabular}

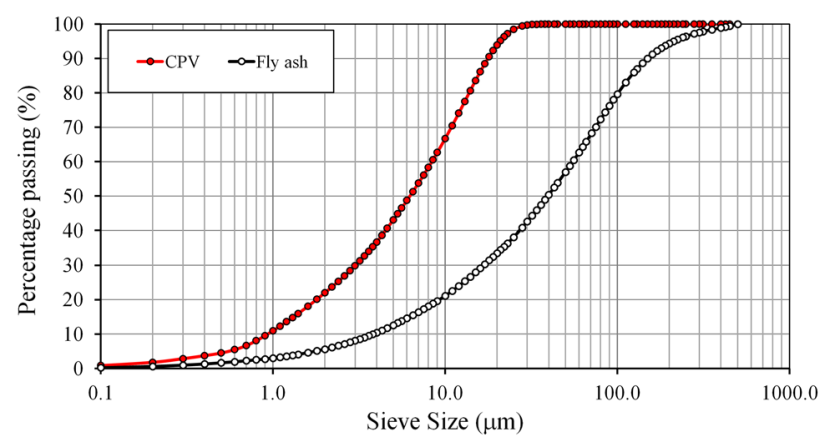

Fig. 3 Laser granulometry of binders

\section{Results and discussions}

\subsection{Cement and fly ash characterization}

CPV cement was used in this study; this cement has specific mass of $3.09 \mathrm{~g} / \mathrm{cm}^{3}$. Table 2 shows the physical and mechanical characteristics of the cement.

Table 3 shows the chemical analysis by X-Ray Fluorescence of CPV and by fly ash. It is important to highlight that fly ash is a silica-aluminous composed addition.

Granulometry binder curves are represented in Fig. 3. According to this figure, $\mathrm{CPV}$ cement is finer than fly ash.

Figure 4 and Table 4 have the diffratogram of fly ash in anhydrous state, indicating the mullite $\left(\mathrm{Al}_{6} \mathrm{Si}_{2} \mathrm{O}_{13}\right)$ and hematite $\left(\mathrm{Fe}_{2} \mathrm{O}_{3}\right)$ peaks. According to Hoppe Filho [7], it is possible to detect the presence of an amorphous halo by evaluating the XRD diffractograms of mineral additions in anhydrous state. The addition pozzolanic potential is directly proportional to the amorphous halo. The formation of the amorphous halo in Fig. 4 indicates the reactive tendencies of the addition.

According to results from the modified Chapelle test [16], fly ash has $408 \mathrm{mg} \mathrm{Ca}(\mathrm{OH})_{2} / \mathrm{g}$ of pozzolan. This

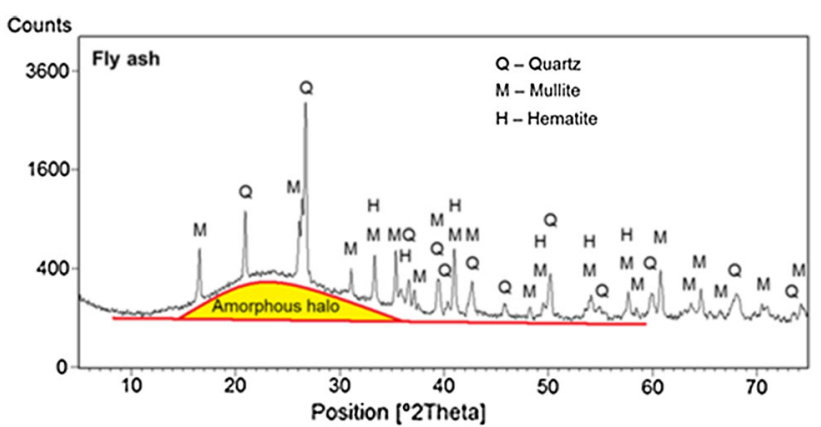

Fig. 4 Fly ash sample diffratogram

Table 4 Minerals found in the fly ash diffractogram

\begin{tabular}{llll}
\hline Reference code & Compound & Chemical formula & Mineral \\
\hline $46-1045$ & Silicon dioxide & $\mathrm{SiO}_{2}$ & Quartz \\
$15-0776$ & Silica aluminate & $\mathrm{Al}_{6} \mathrm{Si}_{2} \mathrm{O}_{13}$ & Mullite \\
$01-1053$ & Iron oxide & $\mathrm{Fe}_{2} \mathrm{O}_{3}$ & Hematite \\
\hline
\end{tabular}

value is below the limit of $436 \mathrm{mg} \mathrm{Ca}(\mathrm{OH})_{2} / \mathrm{g}$ of pozzolan required by Brazilian standards, although very close, indicating the low reaction capacity of this mineral addition. One reason for this result is the fact that fly ash is composed by thicker particles when compared to cement. It should be noted that the fineness of a mineral addition is one of the factors influencing reactivity due to its effect on the surface available for reaction.

\subsection{Theoretical alkaline reserve}

The theoretical alkaline reserve of the samples was calculated from the effective consumption of the cement and from the potential consumption of the calcium hydroxide 
Fig. 5 Theoretical calcium hydroxide consumption calculation, in absolute volume, based on the capacity determined by the modified Chapelle test (NBR 15895 2010)

Fig. 6 Theoretical alkaline reserve calculation based on the capacity determined by the modified Chapelle test (NBR 15895 2010)
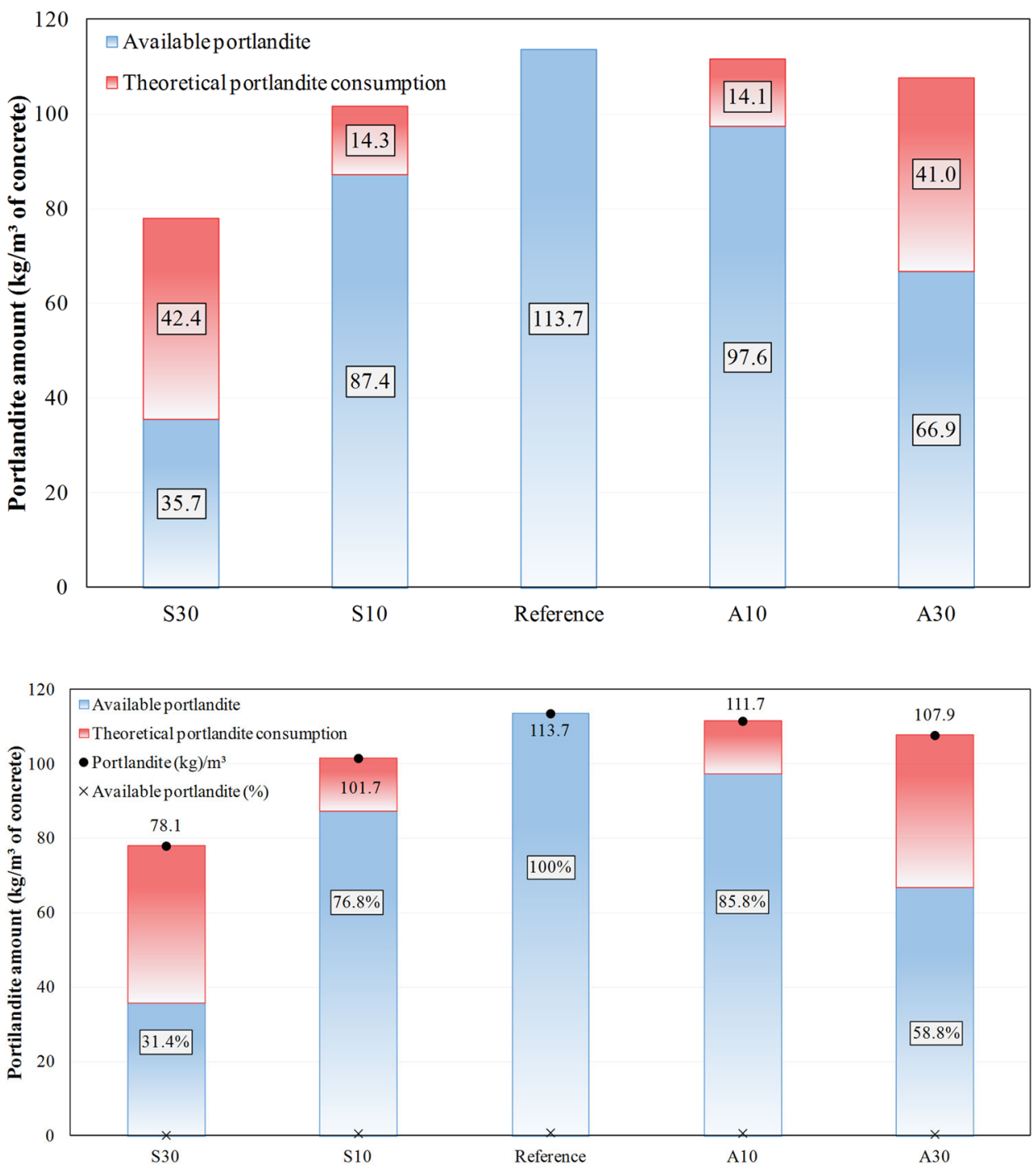

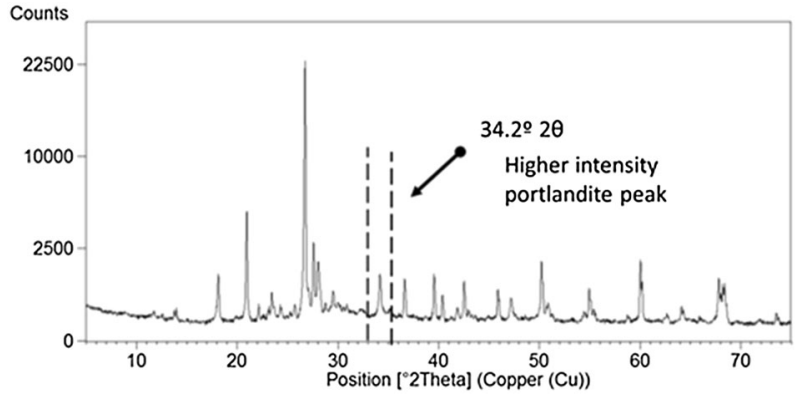

Fig. 7 Diffratogram of the sample of reference concrete mortar

by the fly ash as determined by the Chapelle test. In Fig. 5, the remaining theoretical alkaline reserve available for carbonation is represented by the blue color. The mass of calcium hydroxide consumed by the fly ash in each mix proportioning is represented in red.

All data shown in Fig. 5 were reproduced in Fig. 6 as percentages regarding the alkaline reserve of the reference mix proportions in order to facilitate the interpretation of the alkaline reserve. This way, it is evident that in the case of replacement (S10 and S30), alkaline reserve ranges between 76.8 and $31.4 \%$ of the lime available in reference series. When using fly ash as an addition to Portland cement, the alkaline reserve ranges from 85.8 to $58.8 \%$ of available lime, for A10 and A30, respectively.

The alkaline reserve decrease can be explained by the pozzolanic effect which occurs from the calcium hydroxide consumption, the main responsible for the high alkalinity of the concrete pores' aqueous solution. Concretes with pozzolanic mineral additions tend to have a smaller alkaline reserve; just as pointed by by Papadakis [11], Siddique and Khan [17], and this may indicate a higher susceptibility to the advancing of the carbonation front.

In the case of being used as a partial replacement, the decrease of the alkaline reserve is greater than in the case of replacement because, besides the pozzolanic reactions, 


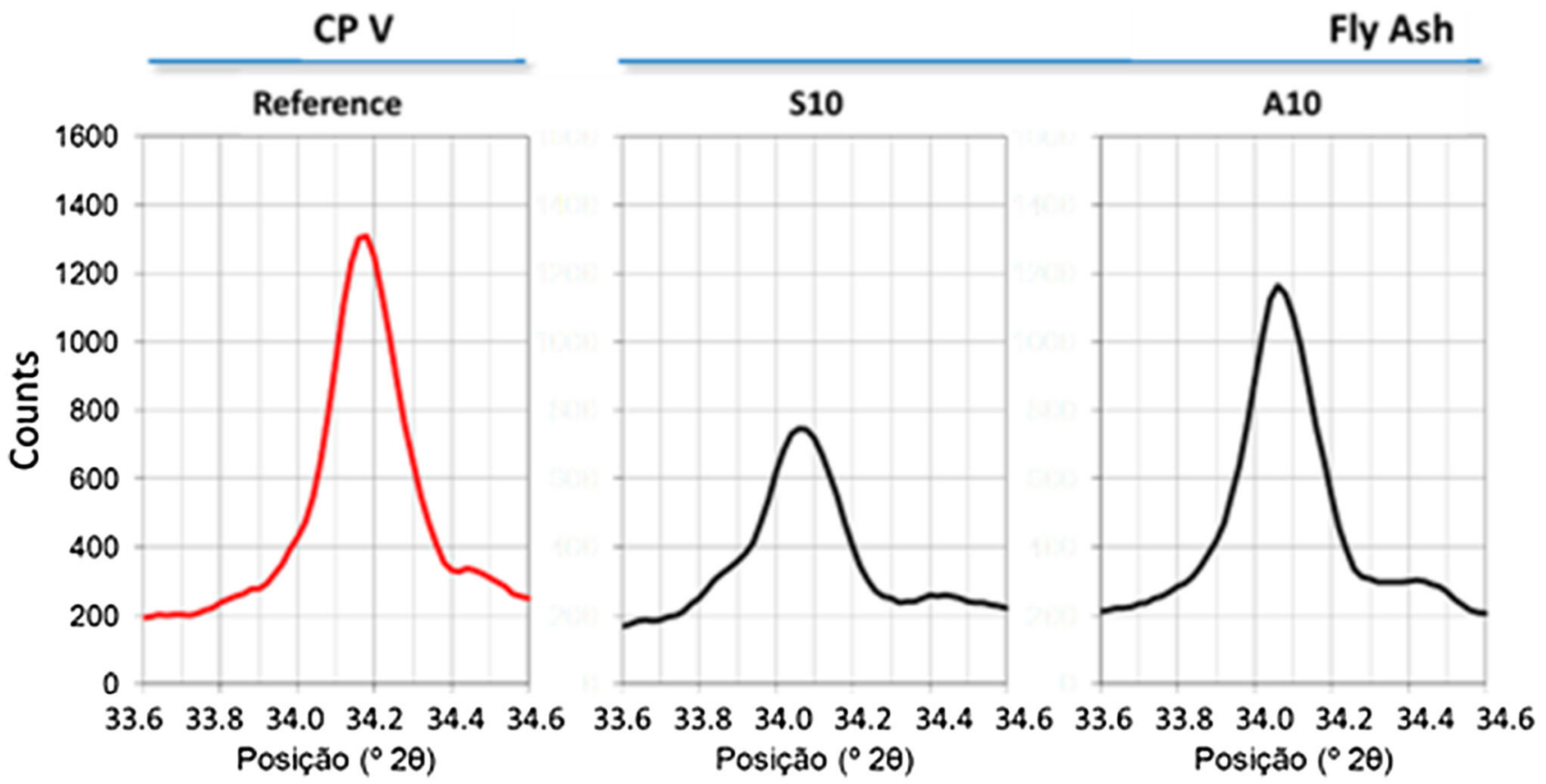

Fig. 8 Diffractometer considering a $10 \%$ fly ash variation
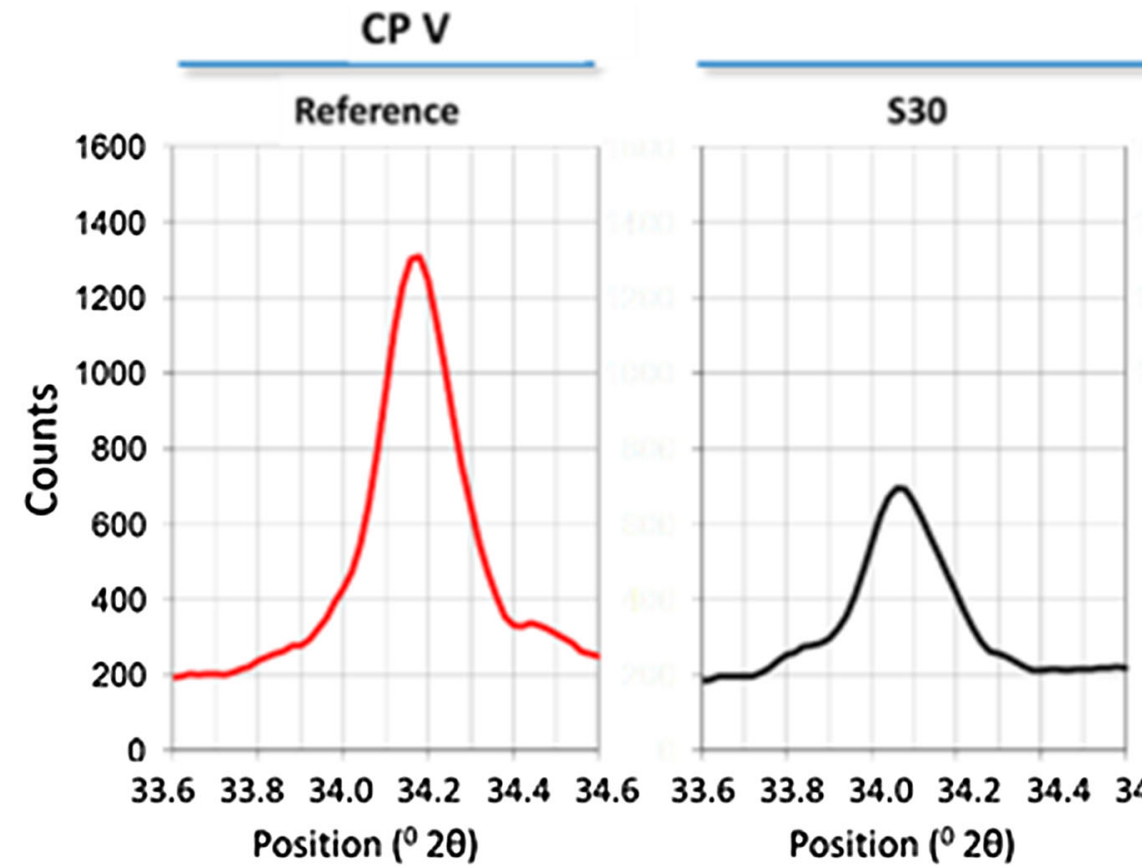

Fly Ash

$\begin{array}{llllll}33.6 & 33.8 & 34.0 & 34.2 & 34.4 & 34.6\end{array}$ Position $\left({ }^{\circ} 20\right)$

Fig. 9 Diffractometer considering a $30 \%$ fly ash variation

there is also the effect of the decrease of the Portland cement amount generating portlandite during hydration.

\subsection{Study about alkaline reserve using XRD}

According to Nita and John [18], in the hydration of Portland cement without pozzolana, the intensity of portlandite peaks increases with the course of the hydrations of alita and belita, provided that there is no carbonation. In a paste of cement with pozzolana, some or the whole calcium hydroxide is consumed by reactions with pozzolana, which normally triggers a decrease of intensity in the corresponding peaks. Besides influencing factors such as degree of crystallinity and variations in the 
orientation of crystals while preparing the samples, the variation of the intensity of portlandite peaks by DRX for the study of pozzolans is related with their amount in the cementitious composite [19]. Voglis et al. [20], Antiohos et al. [21], Cabral [22], Dantas [23], Picanço et al. [24], Vaitkevicius et al. [25], Gómez-Zamorano et al. [26], AboEl-Enein et al. [27] and Silva [28] also used the reasoning of comparing the intensity of peaks for studying pozzolans, as other works from the research group that created this paper also did. Publications of Gobbi [29], Raisdorfer [30], Medeiros et al. [31] and Medeiros et al. [32] and Hoppe Filho et al. [33] are examples of this.

Therefore, in this part of the study, the X-Ray Diffraction technique was applied to samples of concrete mortar and the evaluation was focused in comparing the portlandite peak intensity (located at $34,2^{\circ} 2 \theta$ in the diffractograms). The following assumption was adopted: if peak intensity decreases this indicates a decrease of alkaline reserve, under the same test conditions. A small portion of the diffratogram generated by XRD was used for this analysis, as illustrated in Fig. 7.

Figure 8 shows the comparison regarding both the replacement and the addition of $10 \%$ of fly ash. Figure 9 indicates the same kind of comparison but for $30 \%$ of fly ash. It is important to highlight that results were very similar to the ones of the theoretical alkaline reserve, indicating that this comparison of peak intensity is also valid for measuring the alkaline reserve of the concrete.

Note that both series of partial replacements of Portland cement (S10 and S30) resulted in smaller portlandite peak intensities than the series using fly ash as an addition to Portland cement (A10 and A30), as well as happened in the case of the theoretical alkaline reserve (Figs. 5, 6). Figure 10 shows the relation between the two types of studies regarding the alkaline reserve, which has an $R^{2}$ of 0.67 , confirming that there is some relation between the two methods of reading alkaline reserves.

\subsection{Compressive strength and accelerated carbonation}

Figure 11 shows the results of compressive strength in concretes. According to Fig. 11, both substitution and addition of fly ash decrease the compressive strength. Using both 10 and $30 \%$ of fly ash resulted in the same level of compressive strength decrease. Therefore, its use as addition or as replacement indicates the same effect on compressive strength, considering the variability of results and Turkey's statistic test for means comparison (significance level $=95 \%$ ).

Figure 12 shows the effect of the fly ash content in the level of lime available and in carbonation speed. According to Fig. 12, the reference series has the lowest carbonation

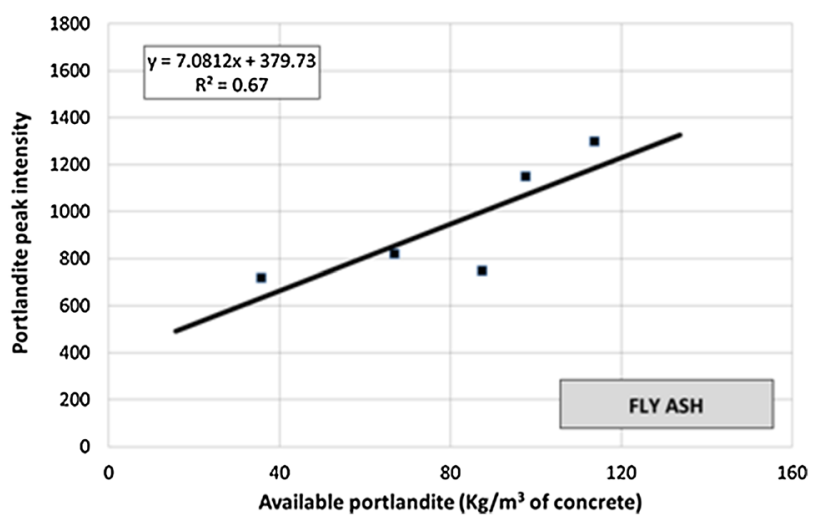

Fig. 10 Relation between the theoretically calculated lime available and the main peak of portlandite in the diffractometer (located at $\left.34.2^{\circ} 2 \theta\right)$

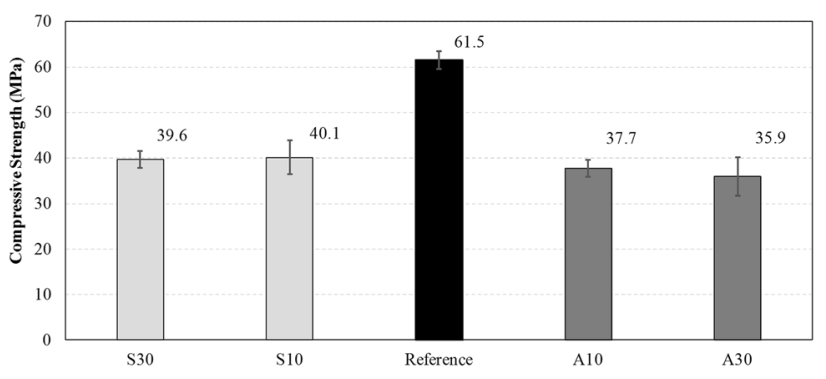

Fig. 11 Compressive strengths of the different concrete series used in the experiment
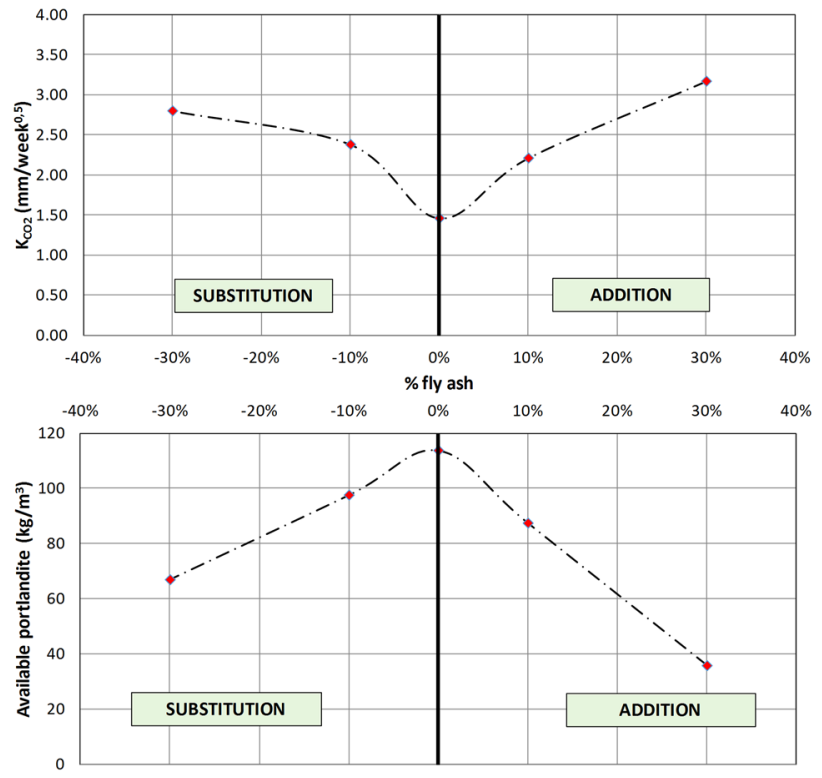

Fig. 12 Variation of carbonation coefficient $K_{\mathrm{CO} 2}$ regarding the fly ash level in concrete and regarding the available lime level (theoretical reserve of portlandite)

speed. Thus, the use of fly ash as addition or as a partial replacement of Portland cement, resulted in an increase of concrete carbonation speed. Figure 12 also shows that the 

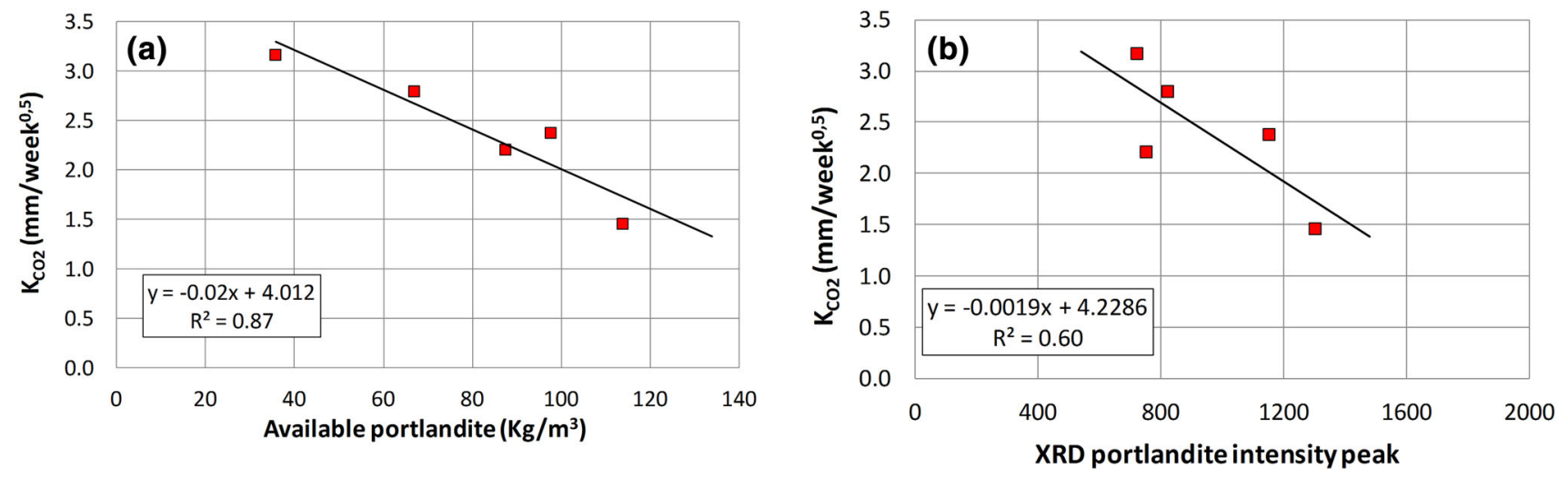

Fig. 13 Relation between carbonation coefficient and alkaline reserve as measured by available lime (theoretical calculation) and by Portland cement intensity peak

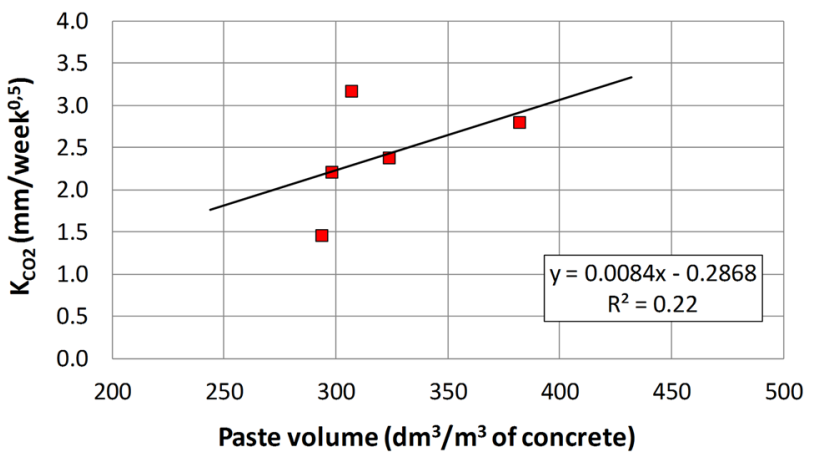

Fig. 14 Relation between carbonation coefficient and volume of the concrete paste $\left(\mathrm{dm}^{3} / \mathrm{m}^{3}\right)$

alkaline reserve criterion had an important role in carbonation speed. It is possible to note that the use of fly ash resulted in a decrease of the alkaline reserve and compromised the efficiency of the concrete regarding the protection against the carbonation process.

Figure 13 shows two graphs correlating $K_{\mathrm{CO} 2}$ with two types of readings regarding the alkaline reserve of portlandite of the concrete, the theoretical calculation of calcium hydroxide and the main peak of portlandite in the diffractometer (located at $34,2^{\circ} 2 \theta$ ). It is possible to verify that, in the case of available lime, correlation $R^{2}$ is 0.87 , indicating strong links between data. In the case of the diffractometer peak intensity comparison, there was a tendency of existing a relationship among data, however $R^{2}$ was 0.60 indicating weak dependence. In both cases, the relationship between the results was inverse, the bigger the reserve is, the smaller the carbonation coefficient $\left(K_{\mathrm{CO} 2}\right)$.

Figure 14 shows the variation of carbonation coefficient and the volume of the concrete paste studied. This relation was designed in order to study the possibility that the volume of the paste is an indicative of a greater alkaline reserve per $\mathrm{m}^{3}$ of concrete and also a carbonation speed regulator. However, $R^{2}$ result was 0.22 indicating a very low correlation between data, and it did not prove the relation between those two parameters. This result means that the alkaline reserve does not depend on the volume of the concrete paste, especially in this research that involves concretes with different levels of fly ash, a pozzolanic material.

\section{Conclusions}

Data presented in this paper allow the definition of particular conclusions regarding the materials used. Any generalization must be carefully made since results may vary with changes in concrete composition. Research significances are listed next.

- The use of fly ash both as an addition or as a partial replacement of Portland cement results in decrease of alkaline supply and in increase of carbonation speed.

- The use of fly ash reduces compressive strength at 28 days.

- There is an inverse relation between the alkaline reserve and the carbonation speed of the concrete.

- Paste volume alone does not control carbonation speed when different levels of fly ash are used in the concrete, both as addition or as partial replacements of Portland cement.

- Based on the determination coefficients, the carbonation coefficient is better related with the alkaline reserve calculated using the modified Chapelle test than with the alkaline reserve obtained from XRD analysis.

\section{Compliance with ethical standards}

Conflict of interest On behalf of all authors, the corresponding author states that there is no conflict of interest. 


\section{References}

1. Wang S, Baxter L (2007) Comprehensive study of biomass fly ash in concrete: strength, microscopy, kinetics and durability. Fuel Process Technol 88(11-12):1165-1170. doi:10.1016/j. fuproc.2007.06.016

2. Hoppe FJ, Souza DJ, Medeiros MHF, Pereira E, Portella KF (2015) Concrete attack by sodium sulfate: mineral additions as a mitigation tool. Cerâmica (São Paulo. Impresso) 61(358):168-177. doi:10.1590/0366-69132015613581905 (in Portuguese)

3. Choi Y, Kim J, Lee K (2006) Corrosion behaviour if steel bar embedded in fly ash concrete. Corros Sci 48(7):1733-1745. doi:10.1016/j.corsci.2005.05.019

4. Chindaprasirt P, Jaturapitakkul C, Sinsiri T (2005) Effect of fly ash fineness on compressive strength and pore size of blended cement paste. Cem Concr Compos 27(4):425-428. doi:10.1016/j. cemconcomp.2004.07.003

5. Chindaprasirt P, Jaturapitakkul C, Sinsiri T (2007) Effect of fly ash fineness on microstructure of blended cement paste. Constr Build Mater 21(7):1534-1541. doi:10.1016/j.conbuildmat.2005. 12.024

6. Shehata MH, Thomas MDA (2000) The effect of fly ash composition on the expansion of concrete due to alkali-silica reaction. Cem Concr Res 30(7):1063-1072. doi:10.1016/S00088846(00)00283-0

7. Hoppe FJ (2008) Cement, fly ash and hydrated lime system: hydration mechanism, microstructure and concrete carbonation. Doctoral thesis, University of São Paulo-USP, São Paulo, Brazil (in Portuguese)

8. Hoppe FJ, Medeiros MHF, Pereira E, Helene P, Isaia GC (2013) High-volume fly ash concrete with and without hydrated lime: chloride diffusion coefficient from accelerated test. J Mater Civ Eng 25(3):411-418. doi:10.1061/(ASCE)MT.1943-5533. 0000596

9. Heede V, Beile N (2014) A service life based global warming potential for high-volume fly ash concrete exposed to carbonation. Constr Build Mater 55:183-193. doi:10.1016/j.conbuildmat. 2014.01.033

10. Possan E (2010) Carbonation modeling and prediction of service life of concrete structures in urban environment. Doctoral thesis, Federal University of Rio Grande do Sul-UFRGS, Porto Alegre, Brazil (in Portuguese)

11. Papadakis VG (2000) Effect of supplementary cementing material on concrete resistance against carbonatation and chloride ingress. Cem Concr Res 30(2):291-299. doi:10.1016/S00088846(99)00249-5

12. NBR 5736 (1999) Pizzolanic Portland cement-Specification. Brazilian Association of Technical Standards-ABNT, Rio de Janeiro, Brazil (in Portuguese)

13. NBR 11578 (1997) Portland composite cement-Specification. Brazilian Association of Technical Standards-ABNT, Rio de Janeiro, Brazil (in Portuguese)

14. Tuutti K (1982) Corrosion of steel in concrete. CBI Forskning research. Swedish Cement and Concrete Research Institute, Stockholm

15. Cabrera J, Rojas MF (2001) Mechanismo of hydratation of the metakaolin-lime-water system. Cem Concr Res 31(2):177-182. doi:10.1016/S0008-8846(00)00456-7

16. NBR 15895 (2010) Pozzolanic materials-determination of calcium hydroxide fixed-modified Chapelle method. Brazilian Association of Technical Standards-ABNT, Rio de Janeiro, Brazil (in Portuguese)

17. Siddique R, Khan MI (2011) Supplementary Cementing Materials. Springer, Berlin
18. Nita C, John VM (2007) Pozzolanic materials: the metakaolin and the silica fume. Technical Bulletin of the Polytechnic School of USP, BT/PCC/451, p 1-13

19. Nita C (2006) Use of pozzolans in cement composites reinforced with cellulose fibers and PVA. Master thesis, University of São Paulo-USP, São Paulo, Brazil (in Portuguese)

20. Voglis N, Kakali G, Tsivilis S (2001) Identification of composite cement hydration products by means of X-ray diffraction. Mikrochim Acta 126:181-183. doi:10.1007/s006040170051

21. Antiohos SK, Papadakis VG, Chaniotakis E, Tsimas S (2007) Improving the performance of ternary blended cements by mixing different types of fly ashes. Cem Concr Res 37:877-885. doi:10. 1016/j.cemconres.2007.02.017

22. Cabral KC (2001) Effect of the addition of light mineral fillers on the mechanical strength of grouts for cementing offshore wells. Doctoral thesis, Federal University of Rio Grande do NorteUFRGN, Natal, Brazil (in Portuguese)

23. Dantas HO (2013) Evaluation of the effects of the addition of powdered and colloidal nanosilica in Portland cement pastes. Master thesis, Federal University of Pernambuco-UFPE, Recife, Brazil (in Portuguese)

24. Picanço MS, Angélica RS, Barata MS (2014) Portland cements activated with pozzolanic zeolitic sandstone. J Matér 19(2):68-80. doi:10.1590/S1517-70762014000200002

25. Vaitkevicius V, Serelis E, Hilbig H (2014) The effect of glass powder on the microstructure of ultra high performance concrete. Constr Build Mater 68:102-109. doi:10.1016/j.conbuildmat. 2014.05.101

26. Gomez-Zamorano LY, Garcia-Guillen G, Acevedo-Davila JL (2015) Study on the hydration of Portland cement paste replaced with blast furnace slag, fly ash, and metakaolin: effect on the usage of two superplasticizer additives. J Alconpat 5(3):193-208. doi:10.21041/ra.v5i3.89

27. Abo-El-Enein SA, El-Kady G, El-Sokkary TM, Gharieb M (2015) Physico-mechanical properties of composite cement pastes containing silica fume and fly ash. Hous Build Natl Res Cent (HBRC Journal) 11:7-15. doi:10.1016/j.hbrcj.2014.02.003

28. Silva KDC (2016) Evaluation of the pozzolanic activity of waste from rock wool, fiberglass and glass wool. Master thesis, Federal University of Ouro Preto-UFOP, Ouro Preto, Brazil (in Portuguese)

29. Gobbi A (2014) Pozzolanic activity of mineral additions according to NBR 5751/2012 and NBR 5752/2012: a critical analysis based on complementary methods. Master thesis, Federal University of Paraná-UFPR, Curitiba, Brazil (in Portuguese)

30. Raisdorfer JW (2015) Influence of the addition or substitution of mineral additions to Portland cement: effects on carbonation, capillary absorption and concrete resistivity. Master thesis, Federal University of Paraná-UFPR, Curitiba, Brazil (in Portuguese)

31. Medeiros MHF, Hoppe FJ, Gobbi A, Pereira E (2015) High reactivity pozzolan: a critical evaluation of pozzolanic activity index (PAI) with lime using X-ray diffraction. J Ambiente Construído (Online) 15:19-29. doi:10.1590/s167886212015000300023

32. Medeiros MHF, Hoppe FJ, Raisdorfer J (2017) Influence of silica fume and metakaolin in carbonation rate of concrete: relationship with strength, absorption and w/c ratio. Ambiente Construído (Online), (NO PRELO)

33. Hoppe FJ, Garcez MR, Medeiros MHF, Silva Filho LCP, Isaia GC (2017) Reactivity assessment of residual rice-husk ashes. J Mater Civ Eng 1:04017003. doi:10.1061/(ASCE)MT.19435533.0001820\#sthash.efYp6e30.dpuf 